\title{
口腔インプラントによる上顎洞炎
}

\author{
鎌田 守人・島津＼cjkstart薰*・青木 秀哲* \\ 城山 明宏*・毛利 大介*・毛利 学*
}

\section{Maxillary Sinusitis Caused by Oral Implants}

\author{
Morito Kamada \\ (Ogata ENT Clinic) \\ Kaoru Shimazu, Hideaki Aoki, Akihiro Shiroyama, \\ Daisuke Mouri and Manabu Mouri \\ (Osaka Dental University)
}

Dental implants are widely used for partially or fully edentulous patients, however, cases of maxillary sinusitis caused by dental implants have been reported.

We treated 26 such patients in Osaka Dental University hospital from 1973 to 2001 . A clinical analysis was performed in 27 cases, and the results were as follows:

1. Of the 26 cases, 10 patients were males and 16 patients were females; the mean age was 54.5 years old.

2. Type of implants: 19 patients received endosteal implants, 7 were fitted with subperiosteal implants and 1 got endodontic and endosteal implants.

3. The period from implant insertion to symptoms of maxillary sinusitis: 7 patients $(25.9 \%)$ had onset within a month and 9 patients had onset within a year (33. 3\%).

4. Period from symptoms to diagnosis: 12 cases (44. 4\%) were diagnosed within a month and 20 cases $(74.1 \%)$ were diagnosed within 6 months.

5. To prevent maxillary sinusitis, investigation of the volume of maxillary bone is required, followed by choosing the proper surgery method and type of implants.

6. It is important to quickly decide whether sinus surgery is necessary or not and to remove implants causing maxillary sinusitis if they perforate the maxillary sinuses.

Key words : maxillary sinusitis, dental implant, clinical analysis

\section{はじめに}

口腔インプラント治療とは, チタンやバイオセラムな ぞの人工材料を歯肉歯槽粘膜下や顎骨内に埋込み，歯の 欠損と咀嚼機能の回復を図る外科的治療法である ${ }^{1}$. 組 織親和性に優れた材料の開発や術式の進歩などにより急 速に普及し, 現在広く臨床で行われている. それに伴い, 埋込まれたインプラントによる上顎洞炎を起こし，イン
プラントを摘出せざるを得ない症例む増加している2) 6). 本稿では, 大阪歯科大学附属病院における口腔インプ ラントによる上顎洞炎症例の臨床的検討を行い, その発 生原因，予防方法，治療方針などを考察した。

対象と方法

大阪歯科大学附属病院において, 1973 年から 2001 年 
までの間に診断および治療を行った，口腔インプラント による上顎洞炎症例のうち，原因インプラントを確定で きた 26 例 27 側を対象とした. 症例の性, 受診時年齢, 原因インプラントの種類，インプラント治療から上顎洞 炎の症状出現までの期間および発症から診断までの期 間，上顎洞炎の治療方法について臨床的検討を行った。

\section{1. 性・年齢}

\section{結＼cjkstart果}

26 例中男性 10 例，女性 16 例で，男女比は $1: 1.6$ と 女性症例が多かった。年齢は 19 歳から 87 歳までで，平 均 54.5 歳だった. 50 歳代が男性 3 例女性 5 例, 60 歳代 が男性女性ともに 4 例と，男女とも 50,60 歳代が多かっ た（図 1).

\section{2. 原因インプラントの種類}

口腔インプラントは埋入経路や方法などの違いによ り，歯内骨内インプラント，骨内インプラント，骨膜下 インプラントなどに分類される（図 2)。上顎洞炎の原因 インプラントは, 骨内インプラントが 19 例と最も多く植 立部位はすべて臼歯部だった。その使用材料と形態は金 属ブレード 7 例, 金属スクリュー型またはシリンダー型 6 例でそのうち骨結合型インプラントは 3 例，セラミッ クプレート型 4 例，セラミックスクリュー型 2 例であっ た. 次いで骨膜下インプラントが多く 7 例, 歯内骨内イ ンプラントは 1 例で植立部位は曰歯部だった（表 1).

3. インプラント治療から発症, 発症から診断までの期 間

インプラント埋入手術から上顎洞炎の症状出現までの 期間は, 1 力月 12 年で平均 36.1 力月だった (図 3). 1力

\section{(人)}

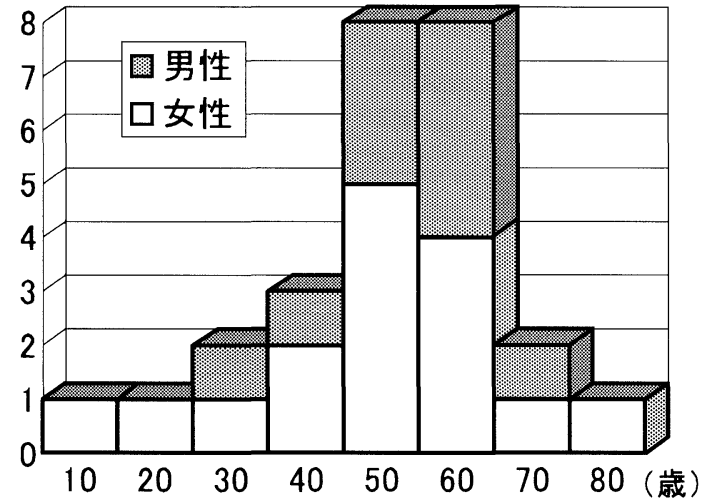

図 1 性・年齢分布
月以内 7 例 $(25.9 \%), 1$ 年以内 9 例 $(33.3 \%), 3$ 年以内 が 18 例（66.7\%） と，比較的早期に症状が現れていた， また発症から診断までの期間は，1カ月以内 12 例（44.4 $\%) ， 6$ 力月以内 20 例 $(74.1 \%)$, 平均 8.9 力月で発症後 かなり早期に診断がされていた（図 4).
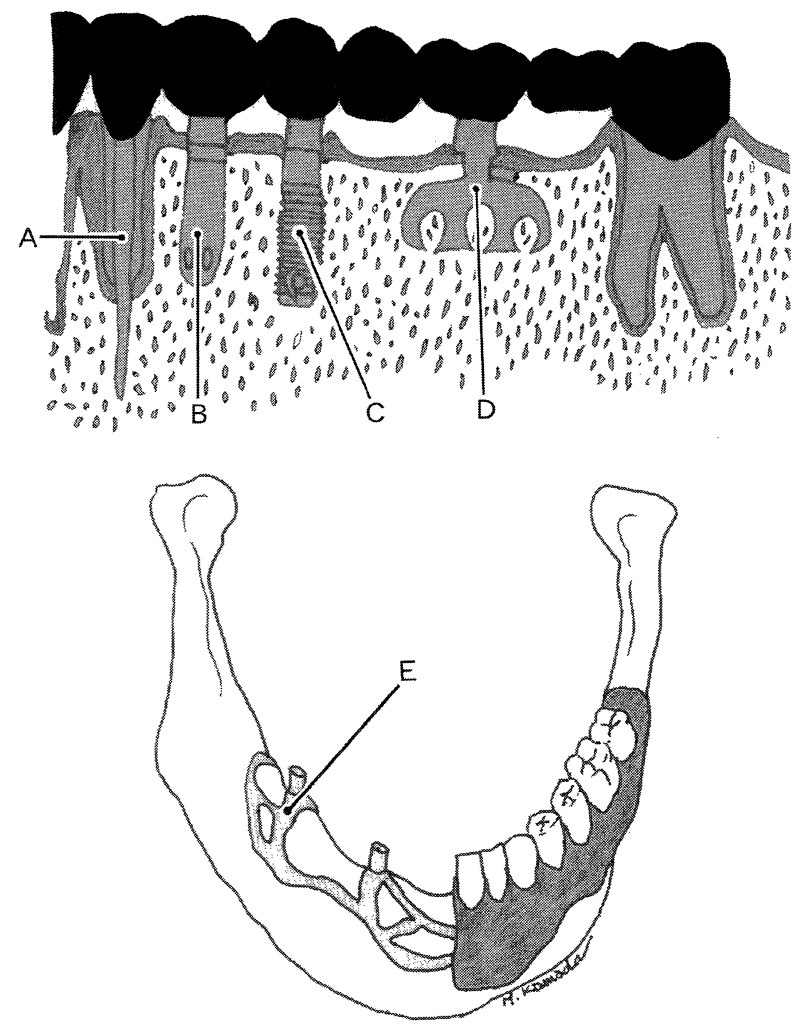

図 2 インプラントの種類

$\mathrm{A}$ ：歯内骨内インプラント, B : 骨内インプラントシリン ダー型, C : 骨内インプラントスクリュー型, D : 骨内イ ンプラントブレード型, $\mathrm{E} ：$ 骨膜下インプラント

表 1 原因インプラントの種類

\begin{tabular}{lccc}
\hline \hline 骨内インプラント & \multicolumn{1}{c}{19 例 } \\
金属ブレード & 7 & \\
金属スクリュー, シリンダー型 & 6 & \\
セラミックプレート型 & 4 & \\
セラミックスクリュー型 & 2 & \\
\hline 歯内骨内インプラント & \multicolumn{3}{c}{1 例 } \\
セラミックピン型 & 1 & \\
\hline 骨膜下インプラント & \multicolumn{3}{c}{7 例 } \\
金属 & \multicolumn{2}{c}{7} & \\
\hline & \multicolumn{2}{c}{ 計 } & 27 例
\end{tabular}


(例)

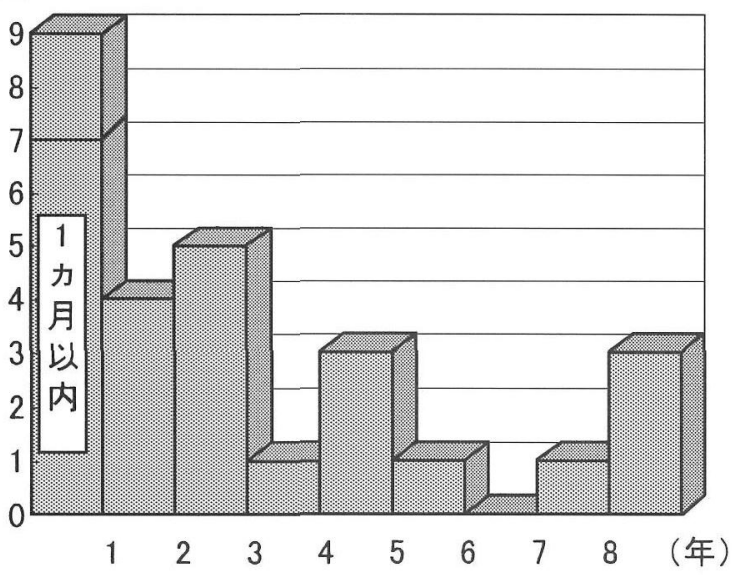

図 3 インプラント手術から発症までの期間

\section{4. 治療方法}

摘出した骨内インプラントと歯内骨内インプラント は，全例上顎洞へ穿孔していた。骨膜下インプラント症
(例)

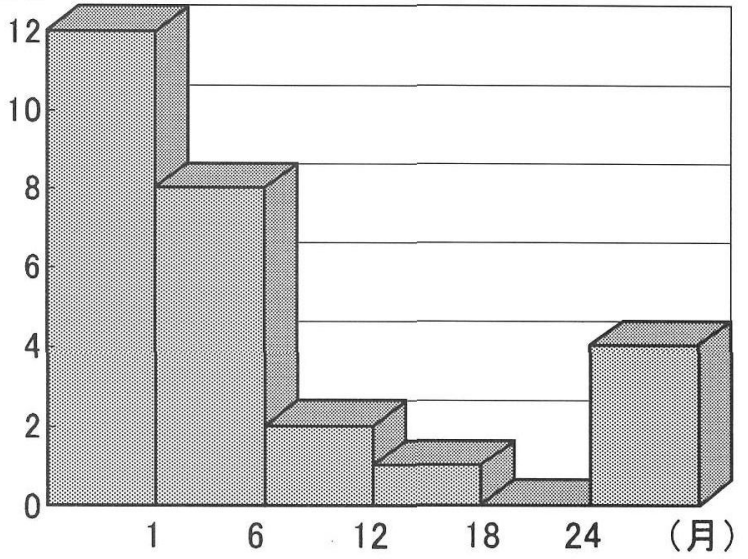

図 4 発症から診断までの期間

例は全例で，金属フレームが上顎骨に接する部分の数カ 所で骨欠損があり，瘦孔を生じていた（図 5)。26 例 27 側の治療方法は表 2 に示すように，インプラント摘出と
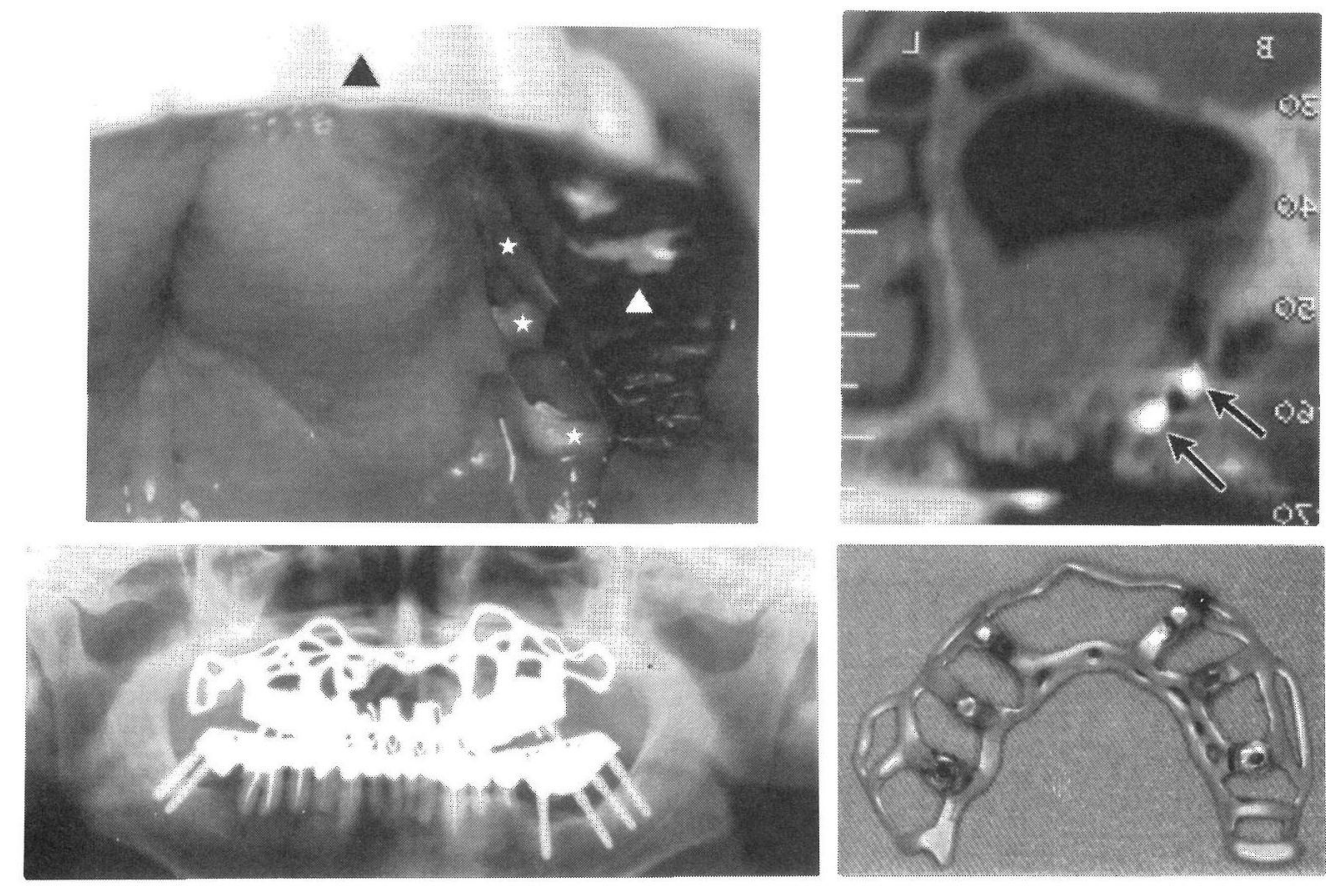

図 5 骨膜下インプラント症例

左上 : 初診時口腔内写真 左上顎臼歯部で骨膜下インプラント金属フレーム（汤）が露出している. $\Delta \triangle$ ：骨膜下インプラント上部構造

左下 : 断層方式パノラマ写真 両側上顎洞底部に混濁像を認める。

右上: CT-MPR 像 左上䫈洞底部に低濃度領域があり, 洞底部外側に骨膜下インプラント金属フレー ムが描出され同部位では上顎骨欠損を認める $(\leftarrow)$.

右下：摘出した骨膜下インプラント 
表 2 治療方法

\begin{tabular}{cccc}
\hline \hline インプラント摘出 & 瘻孔閉鎖 & 上顎洞根治手術 & 症例数 \\
\hline$\bigcirc$ & $\bigcirc$ & $\bigcirc$ & 8 \\
$\bigcirc$ & $\bigcirc$ & $\times$ & 6 \\
$\bigcirc$ & $\times$ & $\bigcirc$ & 2 \\
$\bigcirc$ & $\times$ & $\times$ & 9 \\
$\times$ & $\times$ & $\times$ & 2 \\
\hline 計 & & & 27
\end{tabular}

上顎洞保存的治療を行った例が 9 例，インプラント摘出 と瘦孔閉鎖および上顎洞根治手術を施行した例が 8 例, インプラント摘出と瘻孔閉鎖および上顎洞保存的治療で 軽快した例が 6 例，インプラント除去と上顎洞根治手術 を行った例が 2 例だった。 その他 2 例はインプラントを 摘出せず治療を行った。 1 例は，右臼歯部に骨結合型チ タンスクリューインプラント埋入手術を受け， 1 週間後 に右鼻閉と鼻漏が出現し，さらに 2 週間後に大阪歯科大 学耳鼻咽喉科を紹介受診した。初診時，右中鼻道より膿 汁流出あり，X 線写真で右上顎洞のびまん性混濁を認め た. 右上顎洞粘膜機能検查で機能良好であり, インプラ ントを摘出せず現在経過観察中である。もう 1 例は，右 臼歯部に骨結合型チタンスクリューインプラント埋入手 術を受け, 6力月後に上部構造を装着してから右手や背部 に痛みが出現し，さらに 6 力月後より右鼻閉と鼻漏が出 現し軽快増悪を繰り返すようになり当科紹介受診した。 初診時, 中鼻道より膿汁流出なく, X 線写真では右上顎 洞に軽度の粘膜肥厚像を認めた。抗菌薬ネブライザー治 療と抗菌薬と消炎酵素薬の内服治療を行った. 2 例とも 植立されたインプラントは骨結合型チタンスクリューイ ンプラントで，X 線写真上骨結合している状態で上顎洞 への穿孔は認めなかった。

\section{考 察}

口腔インプラントの歴史は古く, ペルーで発掘された インカ時代のミイラに, 緑色の石で作られた側切歯が上 下顎に植立されており，これが最古といわれている7)。 そ の後 19 世紀末から 20 世紀初頭にかけて，人工歯根の基 礎概念が科学的に整理され，次第に容認され始めた ${ }^{8)}$. そ して埋入経路や埋入部位の異なる歯内骨内インプラン 卜，骨内インプラント，骨膜下インプラントなどが臨床 応用された。それらの歴史と現状について簡単に述べる.

歯内骨内インプラントは, 根管を介し根尖の歯槽骨に
インプラントを植立する治療法で，他のインプラントと は粘膜貫通部を持たないことが大きな違いである. 1940 年 Strock ら ${ }^{9)}$ が最初の成功例を報告したのに始まり，以 後 1980 年代初めまでは盛んに行われたが, その後次第に 用いられなくなり現在はほとんど行われていない。

骨膜下インプラントは, 1943 年 Dahl10) により最初に 行われた. 本邦でも 1970 年代終わりから盛んに実施され てきたが，次第に適応症例は減少してきている.

骨内インプラントは，1969 年 Brånemark ら ${ }^{11)}$ がチタ ンと骨とは直接的に結合する可能性があることを示唆 し，その状態を 1977 年に osseointegration という造語12) で表現して以降, 臨床応用が盛んになり成功率も次第に 向上してきた. 現在では, 骨内インプラントのスクリュー 型や円柱型が主流で，その素材として純チタンとハイド ロキシアパタイトコーティングが多く使用されている. 治療方法は通常 2 段階に分けて行われる. 第 1 段階は顎 骨内に顎内固定装置（フィクスチャー）を埋入し，第 2 段階は骨創の治癒期間をおいて粘膜貫通装置（アバット メント）の連結を行ら，最後にアバットメント周囲の粘 膜治癒を待ち, 印象および咬合採得を行い上部構造とし てのクラウンブリッジ，義歯を装着する．インプラント は義歯が固定されるため, 従来の義歯に比べて天然歯に 近似した強固な咬合支持が得られる利点がある。しかし ながら，上顎臼歯部に施された症例では，他部位に比べ 経過不良例が多(2) 6).

われわれが経験した口腔インプラントによる上顎洞炎 症例 26 例は, 男性 10 例 (38.5\%), 女性 16 例 (61.5\%) と女性が多かった. 年齢は 19 歳から 87 歳まで平均 54.5 歳で，男女とも 50，60 歳代が多かった。 インプラント治 療 1248 本の統計によると, 治療を受けた人は男性 38.6 $\%$, 女性 $61.4 \%$ と女性が多く, 治療時年齢は歯の左失年 齢と相関し $40 \sim 60$ 歳代が多いと報告されている ${ }^{13)}$. こ のようにインプラント治療が男性より女性に多く施行さ れているため, 上顎洞炎を起こした症例も女性が多かっ たと考える．上顎洞炎発症年齢は，インプラント手術か ら発症までの期間が平均約 3 年だったため, インプラン 卜治療時年齢より高く 50,60 歳代が多かったと考える.

インプラント手術から上顎洞炎の症状発現までの期間 は平均 36.1 月で, 1 力月以内が 7 例 $(25.9 \%)$ むりり, 9 例 $(33.3 \%)$ が 1 年以内, 18 例（66.7\%）が 3 年以内 と，比較的早期に症状が現れていた。早期発症例は，イ ンプラント手術時または術後早期にインプラントが沈下 


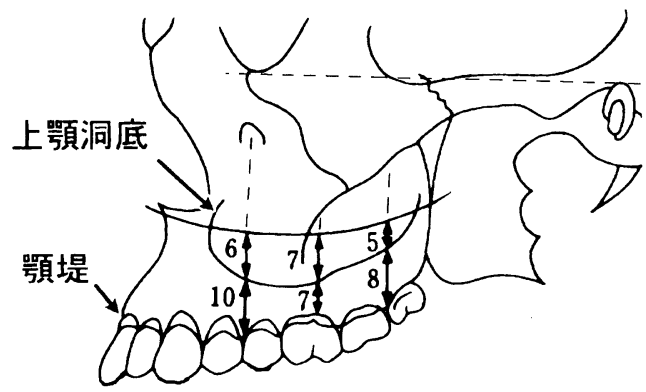

有歯顎

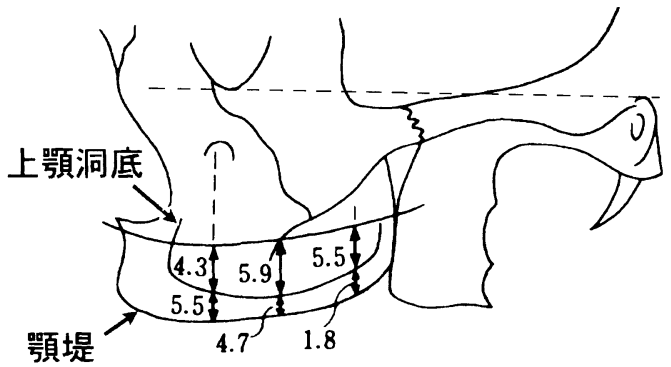

無歯顎

図 6 前鼻棘を含み眼耳平面と平行な面と洞底との距離および洞底と顎堤間距離（単位；mm） (上村次郎：歯科学報 $74: 1860 \sim 1889,1974^{16)}$ より改変)

し，上顎洞穿孔が生じていた。これは，手術手技の問題 や，術前の骨質や骨量の把握不足が原因と考元られた。 長期経過後発症例の原因は, 術後メンテナンスの不足や 咬合荷重の問題など，インプラント体の構造上の問題, 補綴学的, 歯周学的要因が考えられると前田ら ${ }^{4)}$ は報告 している．発症から診断までの期間は，44.4\%（12 例） が 1 力月以内, $74.1 \%$ (20 例）が 6 力月以内と短かった. この期間が短かった原因は，インプラントによる上顎洞 炎の症状が悪臭のある膿性鼻漏や煩部痛などのため, 他 科ではなく耳鼻咽喉科を早期受診したためと思われる.

上顎洞炎の原因となったインプラントは, 骨内インプ ラント 19 例, 骨膜下インプラント 7 例と, 他の報告 ${ }^{516)}$ に比べ骨膜下インプラントが多かった。骨膜下インプラ ント症例は全例で，金属フレームが上顎骨に接する部分 の数カ所で骨欠損があり, 瘦孔を生じていた（図 5)。こ れは適応症例の選択の誤りが原因と考える. 玉置 ${ }^{14)}$ は, 骨膜下インプラントは緻密な皮質骨上に装着されること が必要条件で, 元来骨質が多孔質である上顎骨には骨膜 下インプラントは向かないと述べている．なお骨膜下イ ンプラントと上顎洞との関係の診断には, CT-MPR 法 ${ }^{15)}$ が有用で上顎骨欠損部位が明瞭に描出された（図 5)。ま た摘出した骨内インプラントと歯内骨内インプラント は，全例上顎洞へ穿孔していた。これは以下の解剖学的 特徴によるものと考える. 成人有歯顎上顎洞は, 第 1 小 臼歯近心側から第 3 大曰歯遠心側まで存在し，下方に凸 弯している．無歯顎になると領堤は吸収され，洞底と歯 槽骨頂との距離は短くなり ${ }^{16)}$, インプラント手術時に上 顎洞穿孔を生じる危険性が高くなる（図 6)。また上顎骨 は下顎に比べ皮質骨が薄く, 内部は加齢とともに骨梁が 減少する，そのため咬合圧によりインプラントは沈下し
やすく, 経過中に上顎洞穿孔を生じやすい特徴がある. このように手術時や経過中にインプラントが上顎洞に穿 孔した場合, 高い確率で上顎洞炎を起こすと考えられる. そこで，咬合圧により沈下しにくい骨結合型インプラン トが使用されるようになってきている，われわれの経験 した骨結合型インプラントの 2 例は上顎洞への穿孔はな く,インプラントを摘出せず上顎洞炎の治療を行った. また上記の上顎洞の特徴をふまえ, 洞底に自家骨などを 挿入するサイナスリフト術 ${ }^{17)}$ が考案されている. しかし 移植骨が洞底に固着せず，埋入された骨結合型インプラ ントも上顎洞へ穿孔し上顎洞炎を起こし，インプラント 摘出と瘦孔閉鎖および上顎洞根治手術を行った症例が 1 例あった。

口腔インプラントによる上顎洞炎を予防するには，上 顎骨の骨吸収の程度と洞底の形態を術前に精查し，適応 症例の厳密な選択と症例に合った材料および手術方法の 選択が重要である。

口腔インプラントによる上顎洞炎の治療は，まず上顎 洞根治手術の必要性を早急に診断し，インプラントが上 顎洞へ穿孔していれば，インプラント摘出を含めた外科 的治療を行らことが基本方針だと考える．またインプラ ント治療後早期に摘出する必要が生じた場合，患者に対 する肉体的経済的負担が増大し，またそのために医療紛 争に発展する危険性を含んでいる.

\section{まとめ}

126 例 27 側の口腔インプラントによる上顎洞炎を経 験した。

2 女性 16 例, 男性 10 例と女性が多く, 平均年齢は 54.5 歳だった. 
3 骨内インプラント 19 例, 骨膜下インプラント 7 例, 歯内骨内インプラント 1 例だった。

4 インプラント手術から発症までは, 1 カ月以内 7 例 $(25.9 \%), 1$ 年以内 9 例 $(33.3 \%), 3$ 年以内 18 例 $(66.7$ \%) と早期に症状が現れていた。発症から診断までは, 1 力月以内 12 例（44. $4 \%) ， 6$ 力月以内 20 例（74.1\%）と かなり早期に診断されていた。

5 予防するには, 上顎骨の骨吸収の程度と洞底の形態 を精查し, 適応症例の厳密な選択と症例に合った材料お よび手術方法の選択が重要である.

6 口腔インプラントによる上顎洞炎の治療は, まず上 顎洞根治手術の必要性を早急に診断し，上顎洞穿孔があ ればインプラント摘出を含めた外科的治療を行うことが 基本方針と考光る。

本論文の要旨は, 第 63 回耳鼻咽喉科臨床学会 (平成 13 年, 宜野湾市) で口演した。

\section{参考文献}

1）坪井陽一, 坪井奈々子, 別所和之, 他 : チタンインプラン 卜周囲の骨創の治癒. 頭頸部腫瘍 $21: 493 \sim 500,1995$.

2) 毛利 学, 鎌田守人, 島津 薰, 他：歯科インプラントに よる上顎洞炎. JOHNS $15: 471 \sim 474,1999$.

3) 毛利 学, 島津 薰, 鎌田守人:歯牙・口腔疾患. CLIENT21 No 12 鼻 (夜陣紘治編). $411 \sim 421$ 頁, 中山書店, 東京, 2000 .

4）前田康英, 大村真基, 小笠原健文, 他：インプラント経過 不良 21 例の臨床的検討. 日口腔インプラント誌 $13: 155 \sim$ 162, 2000 .

5）藤島嘉昭, 西原実男, 三宅 実, 他：インプラント経過不 良例における臨床的検討. 日口腔インプラント誌 $13: 650$ $\sim 660,2000$.

6）笠井唯克, 磯貝昌彦, 蔡 豪倫, 他 : 摘出インプラント 24 症例の臨床的評価. 日ロ腔インプラント誌 $13: 428 \sim 436$, 2000 .
7）柳澤定勝：インプラントの歴史的考察. インプラントの基 礎と臨床 (関根 弘, 津留宏道編). $18 \sim 23$ 頁, デンタル ダイヤモンド社, 東京, 1988.

8）川原春幸 : インプラントの歴史. 口腔インプラント学（川 原春幸監修). $3 \sim 16$ 頁, 医歯薬出版, 東京, 1991 .

9) Strock AE and Strock MS : Method of reinforcing pulpless anterior teeth-preliminary report. J Oral Surg $1: 252 \sim 255$, 1943.

10) Dahl GSA : Om möjligheten für implantanten i käken av metallshelett som bas eller retention för fasta eller antagbare protester. Odont Tidsk $4: 440 \sim$ 448, 1943.

11) Brånemark PI, Brine U, Adell R, et al. : Intra-osseous anchorage of dental prostheses. I. Experimetal studies. Scand J Plast Reconstr Surg 3:81 100, 1969.

12) Brånemark PI, Hansson BO, Adell R, et al. : Osseointegrated implants in the treatment of the edentulous jaw; experience from a 10-year period. Scand J Plast Reconstr Surg 11 Suppl 16, 1977.

13）武田孝之：プロトコールと統計. 補綴臨床 $28: 273 \sim 280$, 1995.

14）玉置敏夫：骨膜下インプラント.インプラントの基䃈と臨 床 (関根 弘, 津留宏道編). $258 \sim 269$ 頁, デンタルダイ ヤモンド社, 東京, 1988 .

15）青木秀哲, 島津 薰, 鎌田守人, 他: 歯性上顎洞炎の診断 における CT-MPR 像の有用性. 日鼻誌 40:111 115, 2001.

16）上村次郎: 無歯顎と有歯顎の上顎骨の形態学的研究-1 上 顎洞について一. 歯科学報 $74: 1860 \sim 1889,1974$.

17) Boyne PJ and James RA : Grafting of the maxillary sinus floor with autogenous marrow and bone. J Oral Surg 38:613 616, 1980.

原稿受付：平成14年 9 月 27 日 原稿採択：平成14年11月20日 別刷請求先：鎌田守人 厂650-0027 神戸市中央区中町通3-1-17 緒方耳鼻咽喉科医院 